\title{
КОМПЕТЕНТНІСНИЙ ПІДХІД ДО НАВЧАННЯ УКРАЇНСЬКОЇ МОВИ
}

Лук'яник Л. В. Компетентнісний підхід до навчання української мови.

Статтю присвячено з'ясуванню способів керівництва, які впливають на підготовку майбутніх учителів щуодо формування комунікативної компетенції учнів в умовах реалізачії компетентнісного підходу.

Ключові слова: компетентнісний підхід, комунікативна компетенція учнів.

Лукьяник Л. В. Компетентносный подход к изучению украинского язика.

Статья посвящена раскрытию способов руководства, которые влияют на подготовку будущих учителей к формированию коммуникативной компетенции учеников в условиях реализации компетенческого подхода.

Ключевые слова: компетентносный подход, коммуникативная компетенция учеников.

Lukyanik L. Kompetentnosny approach to the study of the Ukrainian language.

The article is dedicated to the clarification of ways of management that influence the education of future teachers as for forming pupils' communicative competence in the circumstances of using the competence approach.

Key words: competence approach, communicative competence.

Постановка проблеми. У Державному стандарті початкової загальної освіти зазначено, що «основною змістовою лінією мовної освіти в початковій ланці загальноосвітньої школи є мовленнєва, яка передбачає формування та розвиток умінь слухати і розуміти, говорити, читати і писати. Мовна та соціокультурна лінії забезпечують відповідний обсяг знань 3 мови, умінь і навичок їх застосування в мовленнєвій діяльності, а також уявлення про звичаї, побут українського народу, визначні події та постаті в історії України» [2, с. 5-6].

Головним завданням вивчення української мови $є$ навчити учнів спілкуватися рідною мовою в різноманітних життєвих ситуаціях. Спроможність учнів невимушено спілкуватися літературною мовою реалізується через формування лінгвоукраїнознавчої компетенції, зміст якої передбачений мовною, мовленнєвою i соціокультурною компетенціями. Питання компетентнісного підходу в сучасній освіті нині набуває все більшої актуальності, тому що вузловим завданням реалізації означеного напряму є формування навчальних компетентностей.

Комунікативний підхід, який задекларовано як стратегію навчання, концептуальний напрям, передбачає оволодіння правилами україномовного спілкування. Комунікативною лінією змісту навчання передбачено формування в учнів навичок усного і писемного мовлення, оволодіння культурою оформлення цих двох форм спілкування в різних життєвих ситуаціях.

Аналіз останніх досліджень. Теоретичними засадами дослідження стали лінгвістичні концепції М. Бахтіна, І. Огієнка, О. Потебні, І. Синиці, М. Хомського, Л. Щерби, а саме: сприйняття мови як найважливішого засобу спілкування (В. Виноградов, В. Русанівський, О. Потебня, Л. Щерба), питання диференціації мови та мовлення (Н. Арутюнова, П. Білоусенко, 
Б. Головін, О. Мельничук), засвоєння мови як знакової системи (О. Білецький, I. Мєщанінов, І. Огієнко, О. Потебня, М. Хомський), провідні ідеї дидактів та методистів щодо комунікативного підходу до навчання (М. Вашуленко, О. Біляєв, Є. Голобородько, І. Гудзик, Г. Коваль, Н. Пашківська, М. Пентилюк, О. Савченко, О. Хорошковська); наукові дослідження в галузі історичної діалектології (М. Дзендзелівський, С. Бевзенко, Ф. Жилко, І. Матвіяс).

Методичною основою дослідження $є$ праці науковців-методистів О. Біляєва, Є. Голобородько, Ю. Караулова, Т. Ладиженської, Л. Мацько, Н. Пашківської, М. Пентилюк, В. Русанівського, М. Вашуленка, Л. Скуратівського, Л. Симоненкової, Г. Шелехової, О. Купалової.

У Концепції навчання державної мови в школах України визначено найважливіші уміння i навички, що складають основу мовленнєвої компетенції: уміння вести діалог із додержанням вимог українського мовленнєвого етикету в різних життєвих ситуаціях, уміння створювати усні монологічні висловлювання, уміння адекватно сприймати на слух діалог i монолог, що передбачає зосередження уваги на осмисленні висловлювання, уміння створювати письмові тексти різних стилів та типів мовлення, вміння користуватися різними видами читання [3, с. 17].

Метою статті $є$ з'ясування способів керівництва, що впливають на готовність майбутніх учителів до формування комунікативної компетенції учнів ЗНЗ.

Завданнями статті вважаємо:

- уточнення сутності термінів «компетенція» та «компетентність», доведення їх нетотожності;

- з'ясування способів керівництва, які впливають на підготовку майбутніх учителів до формування комунікативної компетенції учнів.

Виклад основного матеріалу. Термін «мовленнєва компетенція» грунтовно трактує М. Пентилюк, уважаючи його комплексним поняттям, яке передбачає мовленнєві уміння створювати монологічні та діалогічні висловлювання у різноманітних життєвих ситуаціях.

Для нашого дослідження найбільш прийнятним уважаємо визначення поняття «мовленнєвої компетенції», сформульоване А. Богуш: «Визначення різних видів компетенції дає змогу охопити всі сторони мовленнєвої діяльності. Лексична компетенція грунтується на словниковій роботі з дітьми, фонетична - формується у процесі роботи з виховання звукової культури мовлення, граматична компетенція охоплює формування граматичної правильності мовлення, монологічна стосується монологічного мовлення, формування комунікативної компетенції спрямоване на розвиток культури мовленнєвого спілкування, мовленнєвого етикету та етичних норм спілкування» [1, с. 90].

Можна зробити висновок, що компетенція - це обов'язкова норма, вимога до підготовки школяра, а компетентність - це набута компетенція, це результат «надбання» учня.

У 3-4 класах мовно-мовленнєва підготовка молодших школярів набуває чіткої орієнтації: учні удосконалюють набуті вміння та навички, якими вони 
оволоділи у 1, 2 класах. Процес формування лінгвоукраїнознавчої компетенції відбувається такими шляхами:

- розвиток умінь і навичок творчого володіння усним і писемним мовленням у різноманітних ситуаціях спілкування та сферах комунікації;

- практичне застосування знань з рідної (української) мови;

- використання знань 3 української мови як засобу підвищення загальноосвітнього рівня учнів;

- удосконалення та поглиблення кожної з названих вище компетенцій.

Для роботи над формуванням комунікативної компетенції молодших школярів пропонуємо такі діалогічні завдання, що містять етикетні вирази, у процесі виконання яких учитель має намагатися передбачити можливі помилки учнів задля їхнього попередження.

Найулюбленішою формою засвоєння навчального матеріалу в молодшому шкільному віці є гра. Практика свідчить, що у процесі гри молодші школярі творчо мислять, розвивають аналітичні здібності i невимушено засвоюють навчальний матеріал у цікавій і доступній формі. За допомогою рольової гри мовлення учнів стає більш насиченим та аргументованим.

Також доступною формою збагачення словникового запасу молодших школярів є творчі ігри, які сприяють розвитку уяви та фантазії.

Ефективним методом формування мовленнєвої культури учнів $\epsilon$ складання діалогів відповідно до запропонованої ситуації, які можна згрупувати за підвидами: побутові, казкові, діалоги за малюнками. Наводимо зразки вправ, спрямованих на формування комунікативної компетенції.

\section{Вправи на засвосння етикетних мовних формул}

1. У яких ситуаціях доречними будуть такі етикетні мовні формули?

- Перепрошую Вас.

- Прийміть мою щчиу вдячність ...

- Якщьо Вам не важко ...

- 3 приємністю.

- На жаль, не можу.

- Дозвольте поичккавитися.

2. До кого і в яких випадках можна використовувати такі звертання:

- Шановні ... запрошуємо вас.

- Привіт! Як справи?

- Перепрошую, чи не могли б ви ...

- Будьте люб язні.

- Ходи здоровий!

3. Дайте відповідь на запитання: Яку роль в житті людини виконують чарівні слова? Для чого вони нам потрібні? Підберіть основні етикетні формули, які виражають: подяку; згоду, підтвердження, запрошення, прохання, вибачення, відмову, вітання, прощання, побажання.

4. Поясніть, як ви розумієте прислів'я та приказки про мовленнєвий етикет: Дурний язик голові не приятель. Слово - не стріла, а глибще ранить. 
Ласкаве слово - що весняний день. Що маєш сказати - наперед обміркуй. Гостре словечко коле сердечко. Умій вчасно сказати $і$ вчасно замовкнути. Лагідні слова роблять приятелів, а гострі слова - заклятих ворогів. I від солодких слів буває гірко. Дав слово - виконай його. Говоріть так, щоб словам було тісно, а думкам просторо.

5. Доберіть потрібні формули мовленнєвого етикету, які використовують при: привітанні друга 3 днем народження; при зустрічі гостей $з$ господарями дому, що свідчить про гостинність українського народу; на Великдень; на Різдво Христове; на День матері.

6. Дайте відповідь на запитання:

У стосунках з людьми потрібно бути чемним чи брутальним? Поясніть чому.

7. Написати лист рідній людині (бабусі, мамі...) або другові (подрузі), використовуючи емоційно-експресивне звертання, наприклад, любий, дорогий, рідненький ... тощо.

Результати сформованості комунікативної компетенції наводимо в таблиці 1.1.

Таблиия 1

Результати сформованості комунікативної компетенції учнів 3-4 класів (\%)

\begin{tabular}{|c|c|c|c|c|}
\hline \multicolumn{5}{|c|}{ Комунікативна компетенція } \\
\hline 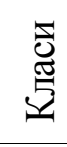 & $\begin{array}{c}\text { Показники } \\
\text { Рівні сформованості } \\
\text { знань } \\
\end{array}$ & $\begin{array}{c}\text { Володіння } \\
\text { етикетними } \\
\text { нормами } \\
\end{array}$ & $\begin{array}{c}\text { Наявність } \\
\text { ініціативності } \\
\text { спілкування } \\
\end{array}$ & $\begin{array}{c}\text { Загальний рівень } \\
\text { сформованості } \\
\text { комунікативної компетенції }\end{array}$ \\
\hline \multirow{4}{*}{$3 K$} & високий & 4,8 & 2,8 & 3,8 \\
\hline & достатній & 28,9 & 26,5 & 27,7 \\
\hline & задовільний & 43,5 & 46,3 & 44,9 \\
\hline & низький & 22,8 & 24,4 & 23,6 \\
\hline \multirow{4}{*}{$3 \mathrm{E}$} & високий & 22,6 & 19,8 & 21,2 \\
\hline & достатній & 43,2 & 38,4 & 40,8 \\
\hline & задовільний & 33,4 & 39,4 & 36,4 \\
\hline & низький & 0,8 & 2,4 & 1,6 \\
\hline \multirow{4}{*}{$4 \mathrm{~K}$} & високий & 5,2 & 3,0 & 4,1 \\
\hline & достатній & 33,7 & 26,3 & 30,0 \\
\hline & задовільний & 41,3 & 45,1 & 43,2 \\
\hline & Низький & 19,8 & 25,6 & 22,7 \\
\hline \multirow{4}{*}{$4 \mathrm{E}$} & високий & 22,7 & 20,1 & 21,4 \\
\hline & достатній & 47,6 & 38,2 & 42,9 \\
\hline & задовільний & 29,7 & 40,1 & 34,9 \\
\hline & низький & 0,0 & 1,6 & 0,8 \\
\hline
\end{tabular}

Перевірка комунікативної компетенції учнів здійснювалася шляхом поновлення деформованих речень, виправлення мовленнєвих недоліків і їх заміною нормативними відповідниками.

Отже, комунікативна компетенція є базовим складником компетентнісного підходу в сучасній педагогічній освіті, оскільки передбачає оволодіння учнями всіми видами компетенцій - ключовими, галузевими та предметними.

Підсумовуючи сказане, можна зробити висновок, що формування лінгвоукраїнознавчої компетенції молодших школярів має посідати чільне 
місце в навчальному процесі, носити системний характер і охоплювати всі етапи навчання. На уроках мови наохдіно використовувати завдання для перевірки засвоєння учнями початкових класів змісту лінгвоукраїнознавчої змістової лінії згідно 3 програмовим матеріалом, оволодіння теоретичними положеннями, орфографічними правилами, граматичними засобами, що спонукають учнів до вмінь розпізнавати правильне i помилкове у слововживанні, аналізувати, класифікувати, зіставляти і трансформувати ці вміння в навички.

\section{Література}

1. Богуш А. М. Мовленнєва готовність старших дошкільників до навчання у школі / А. М. Богуш, Н. Є. Шиліна. - Одеса : ПНЦ АПН України, 2003. - 335 с.

2. Державний стандарт початкової загальної освіти // Інформ. зб. Мін-ва освіти і науки України. - 2006. - № 2-3. - С. 3-50.

3. Концепція навчання державної мови в Україні / О. Біляєв, Л. Скуратівський, Л. Симоненкова, Г. Шелехова // Дивослово. - 1996. - № 1. - С. 16-22.

Стаття надійшла до редакції 18.05.2012 р.

УДК 378.147

Т. В. Мандрико, викладач-методист,

Н. В. Михайленко, магістр педагогіки вищої школи, Вищий комунальний навчальний заклад Сумської обласної ради «Лебединське педагогічне училище імені А.С.Макаренка»

\section{РОЛЬ І МІСЦЕ ІКТ У ВИКЛАДАННІ ПСИХОЛОГО-ПЕДАГОГІЧНИХ ДИСЦИПЛІН} дисииплін.

Мандрико Т. В., Михайленко Н. В. Роль і місие ІКТ у викладанні психолого-педагогічних

У статті з'ясовано, які інформаційні технології $i$ на яких етапах навчання використовуютьсяу навчально-виховному прочесі у ВНЗ І-II рівнів акредитачії, щзо сприяє доступу до якісної освіти для всіх студентів.

Ключові слова: молодший спеціаліст, інновачія, педагогічна технологія, IКT.

Мандрыко Т. В., Михайленко Н. В. Роль и место ИКТ в преподавании психологопедагогических дисииплин.

В статье осветлено, какие информационные технологии и на каких этапах обучения используют в учебно-воспитательном прочессе в вузе I-II уровней аккредитации, что обеспечивает доступ к качественному образованию для всех студентов.

Ключевые слова: младший специалист, инновация, педагогическая технология, ИКТ.

Mandryka T., Mikhailenko N. The role and place of ICT in the teaching of psycho-pedagogical disciplines.

It is rotined in the article, what information technologies and on what stages of teaching use in a teaching-edukated process in Higher Educational Establishments I-II levels of accreditation. In fact for today without the use of ICT it is impossible to provide equal access to high-quality education for all students.

Key words: junior specialist, innovation, pedagogical technology, ICT. 